\title{
INTERNATIONAL TRIBUNAL FOR THE LAW OF THE SEA
}

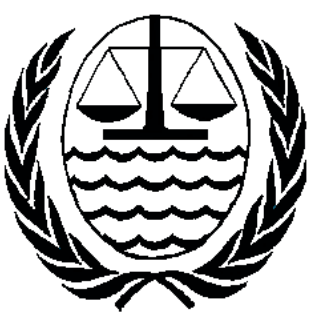

Statement by

\section{H.E. JUDGE RÜDIGER WOLFRUM,}

President of the

International Tribunal for the Law of the Sea

to the Informal Meeting of Legal Advisers

of Ministries of Foreign Affairs

New York

23 October 2006 


\section{Statement by \\ H. E. Judge Rüdiger Wolfrum, President of the International Tribunal for the Law of the Sea, to the Informal Meeting of Legal Advisers of Ministries of Foreign Affairs}

New York, 23 October 2006

Mr. Chairman

Excellencies, Ladies and Gentlemen,

It is a great honour for me to address this meeting of distinguished Legal Advisers for the second time as President of the International Tribunal for the Law of the Sea. I am sincerely grateful for your kind invitation and I very much appreciate the possibility to exchange views on issues of mutual interest.

I feel that it would be useful to take this opportunity to discuss with you two recurring questions of great importance; namely, the competence of the Tribunal in maritime delimitation cases and the Tribunal's advisory function.

\section{The competence of the Tribunal in maritime delimitation cases}

A fundamental innovation of the United Nations Convention on the Law of the Sea of 1982 was the establishment of a comprehensive system for the settlement of disputes consisting of both voluntary and compulsory procedures. This system, which constitutes an integral part of the Convention - namely Part XV - applies to the vast majority of the provisions of the Convention, including those concerning sea boundary delimitation.

The procedures for the settlement of disputes are set out in Part XV of the Convention. According to Part XV, parties to a dispute concerning the Convention who fail to resolve their dispute through voluntary procedures are obliged to resort to compulsory procedures entailing binding decisions provided for in section 2 of Part 
$\mathrm{XV}$. It is noteworthy that, under the Convention, States Parties have accepted compulsory procedures by the mere fact of adhering to the Convention.

As you know, following complicated negotiations, consensus on a dispute settlement system was reached at the Third United Nations Conference on the Law of the Sea through the so-called "Montreux Compromise", which is reflected in article 287. This provision gives States Parties the possibility to choose, by means of a written declaration, one or more means for the settlement of disputes concerning the Convention, namely, the International Tribunal for the Law of the Sea, the International Court of Justice or arbitration. The adjudicating bodies referred to in article 287 have equal standing under the Convention. The jurisdiction of an adjudicating body becomes compulsory when the parties to a dispute have accepted it by virtue of a declaration. Of the present 149 States Parties, so far only 38 have filed declarations, of which 22 have chosen the Tribunal as their preferred means, or one of the means, for the settlement of maritime disputes. In the absence of a declaration, parties are deemed to have accepted arbitration, and this has proven to be the general rule, while selecting the Tribunal or the ICJ remains the exception. I wonder whether this development was anticipated when the Convention was adopted or whether arbitration was meant to be the exception rather than the rule, which it is de facto at the moment. It is therefore to be hoped that an increasing number of States will make declarations with regard to the choice of procedure, as is repeatedly recommended by the General Assembly.

In accordance with article 288 of the Convention, the Tribunal, the ICJ or an arbitral tribunal has jurisdiction over any dispute concerning the interpretation or application of the Convention. In this regard, disputes relating to maritime boundaries are - as a general rule - to be considered disputes concerning the interpretation or application of the Convention. Allow me to explain this point.

First of all, there is a specific reference to Part $X V$ procedures in the provisions governing the delimitation of the exclusive economic zone and the continental shelf. In effect, articles 74 and 83 explicitly provide that, failing agreement on delimitation within a reasonable period of time, the States concerned shall resort to Part XV procedures. 
Secondly, even without an explicit reference of this nature, there can be no doubt that disputes concerning the interpretation or application of other provisions, that is, those regarding the territorial sea, internal waters, baselines and closing lines, archipelagic baselines, the breadth of maritime zones and islands, are disputes concerning the Convention (see articles 3 to 15, 47, 48, 50, 57, 76 and 121).

Thirdly, if a State wishes to exclude certain maritime delimitation disputes from compulsory procedures it has to make a declaration opting out of such means, in accordance with article 298, paragraph 1(a) of the Convention. This declaration can be made in relation to disputes concerning the delimitation of the territorial sea (article 15), the exclusive economic zone (article 74) and the continental shelf (article 83) as well as those involving historic bays or titles. A small number of States have made use of this possibility. Some of these States have excluded delimitation disputes from all of the compulsory procedures while others have made a declaration excluding such disputes from one procedure only.

The fact that a State has excluded maritime delimitation disputes from compulsory procedures by virtue of article 298, paragraph 1(a) of the Convention does not mean that the dispute is entirely exempted from settlement under the Convention. The State concerned will be bound to refer the dispute to compulsory conciliation if the following conditions are met:

- the dispute must be one that has arisen subsequent to the entry into force of the Convention;

- conciliation will be mandatory only where no agreement between the parties is reached within a reasonable period of time;

- any dispute that necessarily involves the concurrent consideration of any unsettled dispute concerning sovereignty or other rights over continental or insular land territory is excluded from the submission to conciliation;

- also excluded from conciliation is any dispute finally settled by an arrangement between the parties. 
Certainly, these conditions are peculiar to the compulsory conciliation procedure; they do not apply to adjudication by the Tribunal, the ICJ or arbitration. This is of particular relevance to the condition regarding "mixed" delimitation cases; namely cases in which a maritime dispute involves the concurrent consideration of any dispute concerning sovereignty or other rights over continental or insular land territory. I will come back to this point in a moment. In addition, it should be noted that, if mandatory conciliation has proven unsuccessful, the dispute may revert to the compulsory system, unless agreed otherwise by the parties.

The general rule that, under the Convention, all maritime delimitation disputes are subject to compulsory binding settlement - unless a declaration to opt out is made - applies to the Tribunal, the ICJ and arbitration. The adjudicating bodies referred to in article 287 are equal in terms of their jurisdiction over sea boundary disputes under Part XV of the Convention. The ICJ may, however, decide maritime delimitation cases beyond Part XV of the Convention on the basis of its jurisdiction as provided for in the Statute of the Court.

A fundamental principle of international adjudication is the consent of the parties. Accordingly, States are free to choose the procedures for resolving their disputes. In line with this principle, the Convention authorizes the parties to a dispute on issues of maritime delimitation, at any time, to agree jointly to submit the dispute to the Tribunal, or any other court or tribunal, by the notification of a special agreement. Through a special agreement, the parties can also overcome any limitations or exceptions to compulsory jurisdiction. Further, the parties to a dispute can always bring the dispute to the Tribunal even when they have chosen other compulsory means under article 287 of the Convention.

With regard to jurisdiction based on a special agreement, the area to be delimited will normally be determined in the special agreement between the parties and nothing prevents them from submitting to the Tribunal any maritime delimitation case involving issues regarding land boundaries or cases involving disputed sovereignty over islands.

As to compulsory jurisdiction - and by this I mean jurisdiction of the Tribunal or 
any other court or tribunal on the basis of article 287 of the Convention - this covers disputes regarding the delimitation of the various maritime zones. In this respect, it may be noted that the competence of the Tribunal, or any other court or tribunal, to deal with the main claim that maritime delimitation be effected according to articles 15,74 or 83 includes the associated question of delimitation over land or islands. I have indirectly alluded to this point already. This approach is in line with the principle of effectiveness and enables the adjudicative body in question to truly fulfil its function.

It is apparent that maritime boundaries cannot be determined in isolation without reference to territory. Moreover, sea boundaries are associated with issues of sovereignty, such as the determination of entitlements over maritime areas, the treatment of islands, the identification of the relevant basepoints - whether they are located at sea, in river mouths or on terra firma - or the fixing of baselines including archipelagic baselines. Such issues of sovereignty and the inter-relation between land and sea are addressed in several provisions of the Convention, for instance, those concerning internal waters, the territorial sea, baselines, archipelagic States and the continental shelf. The presence of islands is a frequent factor in maritime delimitation and the regime of islands is provided in article 121 of the Convention.

Issues of sovereignty or other rights over continental or insular land territory, which are closely linked or ancillary to maritime delimitation, concern the interpretation or application of the Convention and therefore fall within its scope. This may be evidenced by a reading a contrario of article 298, paragraph 1(a), namely, in the absence of a declaration under article 298, paragraph 1(a), a maritime delimitation dispute including the necessarily concurrent consideration of any unsettled dispute concerning sovereignty or other rights over continental or insular land territory is subject to the compulsory jurisdiction of the Tribunal, or any other court or tribunal.

In this connection, I would like to draw your attention to the fact that - apart from contentious proceedings - the parties to a maritime delimitation dispute may also take advantage of the Tribunal's advisory functions. Accordingly, they may request the Tribunal to determine the principles according to which the dispute can 
be settled through direct negotiation. This brings me to the second part of my presentation, namely: the advisory function of the Tribunal.

\section{The advisory function of the Tribunal}

I will deal briefly with this topic.

The advisory function of the Tribunal is twofold. On the one hand, the Seabed Dispute Chamber has jurisdiction to give an advisory opinion with regard to matters pertaining to Part XI of the Convention. On the other hand, the Tribunal may give advisory opinions on the basis of other international agreements. I will explain this in more detail.

Under article 138 of its Rules, the Tribunal may be requested to give an advisory opinion on a legal question if an international agreement related to the purposes of the Convention specifically provides for the submission of a request for such an opinion. The Tribunal's advisory function is based on article 21 of the Statute, which states that the jurisdiction of the Tribunal comprises "all disputes and all applications submitted to it" and "all matters specifically provided for in any other agreement which confers jurisdiction on the Tribunal." Accordingly, future international agreements, for instance, between States or between States and international organizations, could provide for recourse to the Tribunal's advisory procedures. A request for an advisory opinion before the Tribunal is transmitted to the Tribunal by the body or entity so designated in accordance with the international agreement in question. For instance, States could consider submitting an advisory opinion directly to the Tribunal or through an international "body" such as the Meeting of States Parties to the Convention. The rules applicable to advisory proceedings before the Tribunal are set out in the Tribunal's Rules. Interested delegations will find detailed information on the Tribunal's proceedings, including its advisory function, in the Guide to proceedings before the Tribunal, copies of which are available here.

The advisory function of the Tribunal is a significant innovation in the international judicial system and may offer an interesting alternative to contentious proceedings, in particular, in view of its non-binding nature. Through an advisory 
opinion, the requesting body may obtain legal guidance from the Tribunal on a specific question but the requesting body is not bound to accept the conclusions of the Tribunal. This could be advantageous for those seeking an indication as to how a particular dispute may be solved through direct negotiations. As mentioned earlier, the parties to a delimitation dispute could ask the Tribunal to determine the principles and rules of international law applicable to the dispute and undertake thereafter to establish the boundary on that basis. Although advisory procedures have not been used yet, they can certainly assist conflicting parties in reaching a settlement and even prevent them from engaging in a dispute.

Mr. Chairman

Excellencies, Ladies and Gentlemen,

I conclude by expressing my appreciation to you for the opportunity given me to address this meeting. I thank you for your kind attention. 